\title{
Jual Beli Gratis Ongkos Kirim Menurut Islam
}

\author{
Lian Fuad \\ Institut Pesantren KH. Abdul Chalim Pacet Mojokerto \\ Email: cakyan85@gmail.com
}

\begin{abstract}
ABSTRAK
Online buying and selling is growing very rapidly, this is directly proportional to the development of the internet that has penetrated all lines of society, both in terms of economic, political, social and cultural activities. The government in this case supports the development of online buying and selling to reduce the inflation rate due to the use of currency. The government also supports the online buying and selling sector by conducting training in terms of developing business start-ups among young people. Buying and selling online with so much competition, they innovate with a variety of things, one of which is to provide benefits to buyers by eliminating shipping costs which become additional prices that must be borne by the buyer. Buying and selling online can be an attractive magnet to provide benefits for both parties.
\end{abstract}

Keyword: Jual Beli Online, Gratis Ongkos Kirim, Hukum Islam, Online Shopping.

\section{A. Pendahuluan}

Akad jual beli dalam kehidupan manusia merupakan kegiatan yang sangat sering terjadi dalan kehidupan bermasyarakat. Interaksi ini dilakukan oleh semua manusia untuk memenuhi kebutuhan hidup sehari-hari. Dengan interaksi ini, manusia bisa saling memenuhi kebutuhan satu dengan yang lainnya, apalagi dizaman yang serba instan seperti sekarang ini. layanan aplikasi online yang sudah menjadi gaya hidup memudahkan manusia untuk mendapatkan sesuatu yang di inginkan. Islam melihat ini sebagai fenomena baru yang belum ada pada zaman fuqoha qudama’.

Kemudahan internet menjadikan sesorang lebih mudah mengakses barang-barang yang jarang ada dalam pasar offline. Kemudahan ini didukung oleh semakin murahnya jaringan internet yang ditawarkan oleh para provider untuk merangkul konsumen sebanyak- 
banyaknya. Kalangan pengusaha melihat komunitas ini semakin lama semakin besar dan menganggap ini sebagai big market yang harus dirambah secara ekonomi. Pasar bisnis ini memberikan peluang bagi orang-orang yang kreatif untuk melakukan promosi yang tidak memerlukan biaya yang banyak dan membuat setiap orang untuk menjual apa yang dimiliki dengan promosi yang murah.

Perkembangan teknologi internet yang sangat pesat pada saat ini mempengaruhi hampir seluruh aspek kehidupan manusia. Teknologi Informasi yang disertai perkembangan internet saling mendukung satu sama lain sehingga melahirkan konsep Teknologi Informasi berbasis internet yang perkembangannya semakin luas dan semakin banyak diterapkan dalam bisnis perusahaan di berbagai bidang demi tercapainya tujuan yang diinginkan oleh perusahaan ${ }^{1}$.

\section{Pembahasan}

\section{Definisi}

Perkataan jual beli terdiri dari dua suku kata yaitu "Jual dan Beli". Sebenarnya kata "Jual" dan "Beli" mempunyai arti yang satu sama lainnya bertolak belakang. Kata "Jual" menunjukkan bahwa adanya perbuatan menjual, sedangkan "Beli" adalah adanya perbuatan membeli ${ }^{2}$. Makna yang sama sesuai dengan hadits

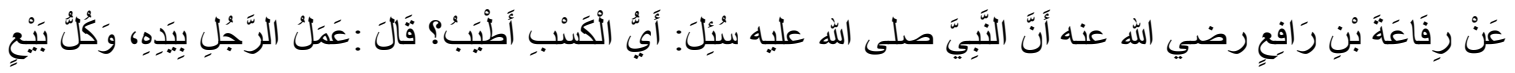

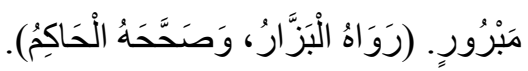

"dari Rifa'ah r.a bahwasannya Nabi Muhammad SAW di tanya : "Pencarian apakah yang paling baik?". Beliau menjawab, "Ialah orang yang bekerja dengan tangannya, dan tiap-tiap jual beli yang bersih"

\footnotetext{
${ }^{1}$ Mahmudi. Analisis dan Perancangan Sistem Penjualan Berbasis Web pada Toko Oncell. Bandar Lampung: Stimik Tektorat, 2003, 1.

${ }^{2}$ Suhrawardi Lubis. Hukum Ekonomi Islam, Jakarta: Sinar Grafika Offset, 2000, 128.
} 
Kata الييع digunakan untuk lawan kata dari الشراء yang berarti membeli ${ }^{1}$. Sedangkan dsecara terminologi, terdapat beberapa definisi, yaitu:

1. Syeikh Taqiyuddin dalam kitab kifayatul akhyar: Saling tukar harta, saling menerima, dapat dikelola (tasharruf) dengan ijab qobul, dengan cara yang sesuai dengan syara ${ }^{2}$.

2. Sayyid Sabiq dalam Fiqh Sunnah: Penukaran benda dengan benda lain dengan jalan saling atau memindahkan hak milik dengan ada penggantinya dengan cara yang diperbolehkan ${ }^{3}$.

3. Menukar barang dengan barang atau barang dengan uang dengan jalan melepaskan hak milik dari yang satu kepada yang lain atas dasar saling merelakan ${ }^{4}$.

4. Menurut ulama madzhab Hanafi,

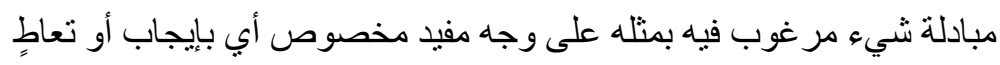

Tukar menukar sesuatu yang diinginkan dengan sesuatu yang diingingkan oleh pihak lain dengan cara yang khusus yaitu ijab atau ta'athi (saling memberi tanpa adanya akad $)^{5}$.

5. Imam Nawawi dalam Majmu': tukar menukar harta dengan harta dengan perpindahan kepemilikan ${ }^{6}$.

Inti dari jual beli adalah berpindahnya kepemilikan barang (مييح) dan harta (نمن). Perpindahan yang parsial tidak bisa dikategorikan jual beli.

\section{Dasar Hukum Jual Beli}

Landasan Jual Beli menggunakan Al-Quran dan Hadits Nabi, disebutkan dalam surat albaqarah ayat 275 :

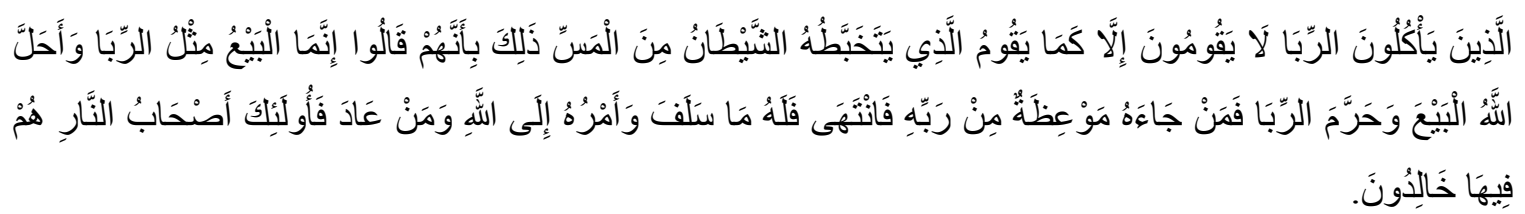

\footnotetext{
${ }^{1}$ Haroen, Nasrun. Fiqih Muamalah. Jakarta: Gaya Media Pratama, 2000, 111.

${ }^{2}$ Taqiyuddin, Abu Bakar, Kifayatul Akhyar, CV Bina Iman, 1995, 535.

${ }^{3}$ Sabiq, Sayyid, Fiqih Sunnah XII, alih bahasa Kamaludin A Marzuki, Bandung: PT Al-Ma'arif, 1987, 126.

${ }^{4}$ Ahmad, Idris, Fiqh al-Syaf'iyah, Jakarta: Karya Indah, 1986, 5.

${ }^{5}$ Alauddin, Bada'ius Shonai 'fi Tartibis Syaroi', Darul Kutub al-Ilmiyah, 1986, 394.

${ }^{6}$ Nawawi, al-Majmu' Syarh Muhadzab, Darul Fikr, juz 9148.
} 
Artinya: Orang-orang yang makan (mengambil) riba tidak dapat berdiri melainkan seperti berdirinya orang yang kemasukan syaitan lantaran (tekanan) penyakit gila keadaan mereka yang demikian itu, adalah disebabkan mereka Berkata (berpendapat), Sesungguhnya jual beli itu sama dengan riba, padahal Allah Telah menghalalkan jual beli dan mengharamkan riba. Orang-orang yang telah sampai kepadanya larangan Tuhannya, lalu terus berhenti (dari mengambil riba), maka baginya apa yang telah diambilnya dahulu (sebelum datang larangan); dan urusannya (terserah) kepada Allah. Orang yang kembali (mengambil riba), maka orang itu adalah penghuni-penghuni neraka; mereka kekal di dalamnya (Q.S.Al.Baqarah: 275)

Ayat diatas menjelaskan kehalalan jual beli dan keharaman semua praktek muamalah yang mengandung unsur riba', karena orang-orang yahudi pada zaman dahulu menyamakan praktek riba dengan jual beli.

Dalam ayat yang lain, Allah juga menyebutkan:

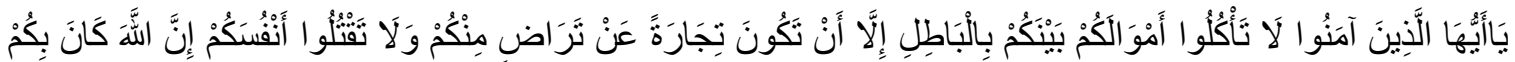
رَحِيمًا

Hai orang-orang yang beriman, janganlah kamu saling memakan harta sesamamu dengan jalan batil, kecuali dengan jalan perniagaan yang berlaku dengan suka samasuka diantara kamu, dan janganlah kamu membunuh dirimu sesungguhnya Allah adalah Maha Penyayang kepadamu. (Q.S. An-Nisa: 29)

Mahallus syahid dalam ayat ini adalah penyamaan jual beli dengan kata تجارة yang berarti perniagaan yang saling ridho antara kedua belah pihak yaitu penjual dan pembeli.

Dalam hadits yang diriwayatkan oleh imam Ahmad,

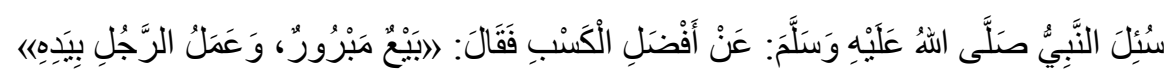
sesungguhnya Rasulullah pernah ditanya "usaha apa yang paling baik? Rasulullah SAW menjawab "Usaha seseorang dengan tangannya sendiri dan setiap jual beli yang mabrur (jujur)”.(HR. Ahmad)

\section{Rukun Jual Beli}


Terjadi perbedaan pendapat tentang masalah penentuan rukun dalam akad jual beli, apakah itu cuma sekedar ijab dan qabul atau shighot, penjual dan pembeli, harta dan barang.

Jumhurul ulama dari kalangan malikiyah, syafiiyah dan hanabilah berpendapat bahwa rukun jual beli itu terdiri dari shighot, penjual dan pembeli, harta dan barang. Alasan yang melandasi pendapat diatas adalah, definisi rukun sendiri adalah sesuatu yang menyebabkan sahnya sesuatu dan bisa di terima akal, baik itu bagian dari esensi sesuatu tersebut atau bukan ${ }^{1}$. Wujudnya jual beli tergantung dengan adanya penjual dan pembeli, barang dan harta. Ketika itu tidak ada, maka tidak dinamakan jual beli.

Ulama madzhab hanafiyah berpendapat bahwa rukun akad jual beli dan akad-akad yang lain hanya satu, yaitu sighot. Golongan ini berpendapat bahwa penjual dan pembeli, barang dan uang termasuk sesuatu yang dibutuhkan untuk terjadinya sighot tetapi bukan bagian dari rukun.

\section{Syarat Jual Beli}

Ulama berbeda pendapat tentang penetapan syarat dalam jual beli. Ada yang menjadikan syarat dalam jual beli menjadi syarat sah jual beli dan ada juga yang menyamakan dengan syarat barang yang dijual.

Syarat barang jual beli, harus memenuhi beberapa syarat, yaitu:

1. Barang harus ada ketika akad jual beli, ulama bersepakat tentang keharaman menjual barang yang tidak ada ketika akad jual beli, seperti menjual sperma (malaqiih), menjual hewan yang masih dalam rahim induknya yang disebut dengan madhomin Seperti dalam hadits:

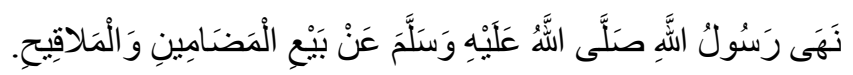

Artinya: rasulullah melarang jual beli madhomin dan malaqiih.(HR. Al-Bazzar)

Dan Rasulullah dalam hadits yang lain menyebutkan tentang larangan jual beli yang mengandung unsur penipuan

\footnotetext{
${ }^{1}$ Syarbini, Mughni Al-Muhtaj, Darul Kutub al-Ilmiyah, 1994, juz 2329.
} 


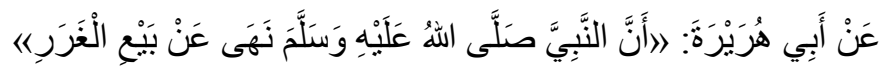

Artinya: dari abi Hurairah, sesungguhnya Rasulullah melarang jual beli yang mengandung unsur penipuan.(HR. Abi Dawud)

2. Barang harus berupa harta, yang dimaksud dengan harta disini adalah sesuatu yang bisa dimanfaatkan oleh kedua belah pihak.

3. Dimiliki secara penuh oleh orang yang melakukan akad. Definisi ini mengecualikan jual beli salam yang mana kepemilikan terjadi setelah beberapa waktu setelah akad dan jual beli sistem wakalah yang sudah mendapatkan otoritas dari pemilik.

4. Barang harus bisa diserahkan, sesuai dengan hadits nabi diatas yang melarang jual beli yang mengandung unsur penipuan.

5. Barang yang diperjualbelikan harus diketahui oleh kedua belah pihak. Barang yang diperjualbelikan harus sesuai dengan spesifikasi yang di ajukan. Perbedaan spsesifikasi bisa menyebabkan munaza'ah atau perdebatan dalam akad. Dalam kategori ini, beberapa ulama menambahkan dengan kriteria bahwa barang juga harus suci dan bukan tergolong barang yang dilarang oleh syariat.

\section{Harga}

Sebelum membahas tentang penggratisan ongkos kirim, penulis akan membahas tentang harga terlebih dahulu. Harga menurut imam Nawawi adalah sesuatu yang digunakan pembeli sebagai ganti untuk mendapatkan barang. Harga salah satu penyusun dalam ma'qud 'alaih, oleh karena itu, ketidaksepakatan antara penjual dan pembeli tentang harga barang, menjadikan batalnya jual beli ${ }^{1}$. Pendapat ini tidak sepaham dengan madzhab hanafiyah yang mengatakan bahwa pokok dari jual beli adalah barang yang dijual, dengan alasan tujuan jual beli adalah pemanfaatan barang, dan harga adalah wasilah untuk mencapai tujuan tersebut. ${ }^{2}$ Pernyataan ini akan menimbulkan keinginan penjual untuk selalu mencari kata sepakat dengan pembeli, sedangkan kerusakan barang akan membatalkan semua kesepakatan yang telah terjadi.

\footnotetext{
${ }^{1}$ Ibid.

${ }^{2}$ Afandi, Amin. Durorul Hukmi fi Syarhi Majallatil Ahkam, Darul Jail, 1991, juz 1122.
} 
Penentuan harga dalam jual beli sangat menentukan terjadinya kesepakatan dalam jual beli, ulama madzhab hanafiyah menjelaskan dengan sangat detail makna tsaman dalam jual beli seperti berikut:

a. Jika salah satu ma'qud 'alaih berupa uang, maka uang bisa dikategorikan tsaman.

b. Jika salah satu ma'qud 'alaih berupa barang yang mempunyai nilai dan satunya berupa harta yang mempunyai nilai yang ditunjukkan dengan nominal didalamnya seperti cek bank, maka harta dengan nominal merupakan tsaman.

c. Jika harta yang digunakan untuk menukarkan sesuatu yang tidak spesifik, maka yang dihitung tsaman adalah yang bersamaan dengan huruf jar ب. Seperti contoh:

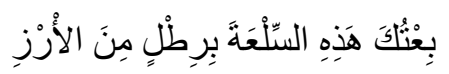

(saya menjual barang ini dengan satu ritl beras). Beras dalam akad ini sebagai tsaman. $^{1}$

Ulama Syafiiyah mendefinisikan tsaman adalah kata dalam akad yang berbarengan dengan huruf jar. . Sedangkan ulama malikiyah lebih terbuka dengan menganggap bahwa uang juga bisa menjadi barang yang diperjualbelikan, karena uang dan barang merupakan objek dalam transaksi.

\section{Gratis Ongkos Kirim}

Sudah jamak perdagangan daring yang menawarkan beragam layanan yang sangat inovatif dan menarik pelanggan karena bebas biaya antar. Situs daring yang menawarkan layanan bebas ongkos kirim yaitu shopee, bukalapak. Dalam situs tersebut, akan diberikan tanda khusus untuk produk-produk yang bisa memberikan gratis ongkos kirim. Gratis ongkos kirim akan membuat kompetisi antar penjual semakin kompetitif dalam memasarkan dan menawarkan produk yang dimiliki. Misalnya Shopee akan memberikan gratis ongkos kirim sampai Rp. 20.000 jika konsumen membeli barang dengan nominal minimal Rp. 90.000 dalam satu kali transaksi per toko. Jika pengiriman membutuhkan lebih biaya lebih dari harga yang ditanggung, maka biaya akan dibebankan kepada pembeli dan biaya akan ditambahkan dengan harga barang.

\footnotetext{
${ }^{1}$ Abidin, Ibn. Raddul Mukhtar Alad Durril Mukhtar, Beirut: Darul Fikr, 1992, juz 4529.
} 
Praktek seperti diatas sejalan dengan akad tabarru'. Kata tabarr'u bersinonim dengan kata tathawwu' تطوع yang didefinisikan oleh Imam Jurjani dalam kitab Ta'rifatnya dengan

$$
\text { اسم لما شرع زيادة على الفرض و الو اجبات }
$$

Sebuah nama terhadap sesuatu yang ditelah disyariatkan atas kelebihan atas kewajiban. ${ }^{1}$

Akad tabarru' adalah transaksi yang tidak bermuatan keuntungan atau transaksi nirlaba. Transaksi ini bertujuan untuk menolong orang lain dalam hal kebaikan. Akad ini tidak mensyaratkan imbalan apapun dalam kebaikannya. Imbalan dalam tabarru' berupa pahala dari Allah swt. Salah satu contoh dalam akad tabarru' hibah.

Akad tabarru' dalam penjualan online dengan gratis ongkos kirim digunakan sebagai daya tarik untuk mendapatkan konsumen sebanyak-banyaknya. Jadi pada dasarnya akad tabarr'u ini memberikan sesuatu. Dalam jual beli gratis ongkos kirim, penjual memberikan free ongkos ${ }^{2}$.

\section{Kesimpulan}

Transaksi jual beli gratis ongkos kirim setelah dikaji dari definisi jual beli, rukun jual beli dan transaksi yang berlaku didalamnya telah memenuhi rukun akad dalam syariah islamiyah. Sedangkan dari segi penggratisan ongkos kirim menggunakan transaksi tabarru' yang membebaskan biaya ongkos jika membeli barang dengan harga minimal yang ditentukan oleh penjual. Pembeli diwajibkan membayar biaya tambahan jika melebihi biaya yang ditanggung oleh penjual. Transaksi dengan model seperti ini untuk menarik pembeli.

\footnotetext{
${ }^{1}$ Al-jurjani. Ta'rifat, Beirut: Darul Kutub Al-Ilmiyah, 1983, 61.

${ }^{2}$ Sholihin, Ahmad Ifham, Buku pintar Ekonomi Syariah, Jakarta: Gramedia Pustaka Utama, 2010, 24.
} 


\section{DAFTAR PUSTAKA}

Abidin, Ibn. Raddul Mukhtar Alad Durril Mukhtar, Beirut: Darul Fikr, 1992.

Afandi, Amin. Durorul Hukmi fi Syarhi Majallatil Ahkam, Darul Jail, 1991.

Ahmad, Idris, Fiqh al-Syaf'iyah, Jakarta: Karya Indah, 1986.

Alauddin, Bada 'ius Shonai'fi Tartibis Syaroi', Darul Kutub al-Ilmiyah, 1986.

Al-jurjani. Ta'rifat, Beirut: Darul Kutub Al-Ilmiyah, 1983.

Arif, M. N. R. Al, Penjualan Online Berbasis Media Sosial dalam Perspektif Ekonomi Islam. Jurnal Ijtihad, Jurnal Wacana Hukum Islam Dan Kemanusiaan, 13(1), 2013.

Haroen, Nasrun. Fiqih Muamalah. Jakarta: Gaya Media Pratama, 2000.

Mahmudi. Analisis dan Perancangan Sistem Penjualan Berbasis Web pada Toko Oncell. Bandar Lampung: Stimik Tektorat.

Nawawi, al-Majmu’Syarh Muhadzab, Darul Fikr.

Sabiq, Sayyid, Fiqih Sunnah XII, alih bahasa Kamaludin A Marzuki, Bandung: PT AlMa'arif, 1987.

Sholihin, Ahmad Ifham, Buku pintar Ekonomi Syariah, Jakarta: Gramedia Pustaka Utama, 2010.

Suhrawardi Lubis. Hukum Ekonomi Islam, Jakarta: Sinar Grafika Offset, 2000.

Syarbini, Mughni Al-Muhtaj, Darul Kutub al-Ilmiyah, 1994.

Taqiyuddin, Abu Bakar, Kifayatul Akhyar, CV Bina Iman, 1995. 